\title{
VULCANISMO RECORRENTE E FEIÇÕES GEOLÓGICAS AFINS EM DIQUES BÁSICO - ULTRABÁSICOS DA PRAIA VERMELHA DO SUL, MUNICÍPIO DE UBATUBA/SP
}

\author{
G.M.Garda ${ }^{1}$ \\ C.Juliani2 \\ H.D.Schorscher ${ }^{2}$ \\ R.Neumann ${ }^{1}$ \\ F.Bohland Neto
}

O costão a NE da Praia Vermelha do Sul, nas proximidades da cidade de Ubatuba, é formado por gnaisses granfticos, provavelmente charnockitos retrometamórficos, do Complexo Cristalino Costeiro do Litoral Norte do Estado de São Paulo. Os gnaisses graníticos exibem uma foliação principal metamórfica de alto grau, de direção geral ENE/subvertical. São cortados por um número elevado de diques máficos de direção $\mathrm{NE}$, verticais a subverticais, produtos de erupções fissurais.

Distinguem-se dois grupos litológicos constituintes dos diques. O primeiro engloba diabásios densos, de cores cinza-esverdeadas, estrutura maciça, textura equigranular média-fina, ocorrem em diques de espessuras em geral métricas. São portadores de xenólitos angulosos das rochas encaixantes e apresentam bordas com larguras de 10 a $20 \mathrm{~cm}$, com leve orientação e foliação de fluxo, vesiculação fraca e fina (poros com diâmetros em geral $<3 \mathrm{~mm}$ ) e efeitos de resfriamento de bordas. Estas rochas são compostas essencialmente de plagioclásio, augita, pigeonita, muito pouca olivina, substituída por serpentina/clorophaefta, biotita e de minerais opacos lamelares (ilmenitas) e granulares finos (magnetita/titanomagnetita). Caracterizam erupções fissurais de fluxo tranqüilo de magmas pobres em voláteis.

\footnotetext{
1Pós-graduação, Departamento de Mineralogia e Petrologia, Instituto de Geociências, USP.

2Departamento de Mineralogia e Petrologia, Instituto de Geociências, USP.
} 
As rochas máficas do segundo grupo diferem em muito dos diabásios, por apresentarem cores cinza-escuras acastanhadas e serem fortemente inequigranulares, porfirfticas, microxenolfticas a até brechóides e fortemente vesiculadas a microcavernosas. Ocorrem interassociadas, em diques compostos, interpretados como resultado de atividade eruptiva recorrente. A recorrência vulcânica iniciar-se-ia com erupções consecutivas por fluxo fissural planar e finalmente culminaria com a formação de condutos vulcânicos, de secção elipsoidal e dimensões métricas. Os condutos elipsoidais distribuem-se ao longo dos diques compostos cortando as rochas com estruturas de fluxo fissural planar. As rochas dos condutos estruturam-se em unidades subconcêntricas de tipo cone-em-cones; inclusive com condutos subseqüentes cortando os anteriores. As espessuras das unidades litológicas das erupções individuais nos condutos cone-em-cone são variáveis, sendo em geral menores (5 a $12 \mathrm{~cm}$ ) nas bordas e atingindo mais de $25 \mathrm{~cm}$ nas partes internas. No mesmo sentido cresce a granulometria e intensificam-se a inequigranulariedade e a vesiculação, tendo as rochas de preenchimento final dos condutos características de brecha soldada. Tratar-se-iam de produtos de erupções progressivamente mais explosivas, a partir de magmas progressivamente enriquecidos em voláteis.

Ao microscópio, as rochas deste grupo apresentam matriz micro a criptocristalina, em parte vitrea-devitrificada. Nesta, distinguem-se augita microprismática a ripiforme de coloração levemente rosada, lamelas de plagioclásio e minerais opacos granulares finos. Os principais fenocristais são clinopiroxênios cálcicos, entre estes titano-augitas fortemente zonadas. subordinadamente olivinas idiomórficas e, em casos, hornblenda castanho-vermelhada, supostamente barkevikftica. Diferenciados finais em segregações microscópicas são invariavelmente portadores de hornblenda barkevikftica e de biotita vermelha, considerada titano-flogopita. Interessante é a ocorrência de analcima em amígdalas e fraturas e provavelmente xenoporfiritica. Os principais xenocristais são de fragmentos de olivinas que apresentam deformação intracristalina de tipo "kink banding" e composição altamente forsterftica, consideradas olivinas do manto superior residual. Os microxenólitos são de rochas dos próprios diques, das encaixantes e micro-nódulos olivínicos e agregados glomeroporfirfticos piroxeníticos do manto superior. Estas rochas são atribuídas preliminarmente aos grupos dos monchiquitos a camptonitos. 